\title{
PERSPECTIVAS DE LA HISTORIA DESDE LA LÍRICA: POESÍA HISTÓRICA DE IDEA VILARIÑO (URUGUAY) Y JULIA OTXOA (PAÍS VASCO)
}

\author{
PERSPECTIVES OF HISTORY THROUGH POETRY: IDEA VILARIÑO'S \\ (URUGUAY) AND JULIA OTXOA'S (BASQUE COUNTRY-SPAIN) HISTORICAL \\ POETRY
}

\author{
Cristian Javier López ${ }^{1}$ \\ Yetzabeth Pérez Anzola²
}

\begin{abstract}
Resumen: La relación Literatura e Historia puede ser rastreada desde los comienzos de la conformación de los pueblos. En el género lírico se observa esta confluencia de la que dan cuenta obras clásicas como el Cantar del Mio Cid (anónimo), en España; y Os Lusíadas (1572), en Portugal. En ellas la referencia histórica era tomada bajo intenciones de orgullo patrio y exaltación de hazañas y héroes, en la poesía más reciente (siglos XX y XXI) es concebida desde actitudes críticas que derivan en denuncias y/o reflexiones sobre las problemáticas contemporáneas, caso de la obra poética de Julia Otxoa (1953) e Idea Vilariño (1920-2009) cuyos textos serán analizados bajo esta óptica.
\end{abstract}

Palabras clave: Julia Otxoa; Idea Vilariño; poesía histórica; historia y literatura.

Resumo: A relação Literatura e Historia pode ser rastreada desde os começos da conformação dos povos. No gênero lírico se observa essa confluência da que dão conta obras clássicas como o Cantar del Mio Cid (anónimo), na Espanha; e Os Lusíadas (1572), em Portugal. Nelas a referência histórica era tomada sob intenções de orgulho pátrio e exaltação de façanhas e heróis, na poesia mais recente (séculos XX e XXI) é concebida desde atitudes críticas que derivam em denúncias e/ou reflexões sobre as problemáticas contemporâneas, caso da obra poética de Julia Otxoa (1953) e Idea Vilariño (1920-2009), cujos textos serão analisados sob essa ótica.

Palavras-chaves: Julia Otxoa; Idea Vilariño; poesia histórica; história e literatura.

A relação Literatura e Historia pode ser rastreada desde os começos da conformação dos povos. No gênero lírico se observa essa confluência da que dão conta obras clássicas como o Cantar del Mio Cid (anónimo), na Espanha; e Os Lusíadas (1572), em Portugal. Nelas a referência histórica era tomada sob intenções de orgulho pátrio e exaltação de façanhas e heróis, na poesia mais recente (séculos XX e $\mathrm{XXI}$ ) é concebida desde atitudes críticas que derivam em denúncias e/ou reflexões sobre as

\footnotetext{
${ }^{1}$ Doctor en Estudios Literarios por la Universidade de Vigo-UVIGO/España, en cotutela con la Universidade Estadual do Oeste do Paraná-UNIOESTE/Brasil. Máster en Teatro y Artes Escénicas por la UVIGO. Licenciado en Letras Portugués-Español por la UNIOESTE. Licenciado en Artes visuales y Licenciado en Música por la Anhanguera-Cascavel/Brasil. Integrante del grupo de investigación "Ressignificações do passado na América Latina: leitura, escrita e tradução de gêneros híbridos de história e ficção - vias para a descolonização”, liderado por el Prof. Dr. Gilmei Francisco Fleck. E-mail: cj_lopez2@hotmail.com.

2 Doctoranda en Letras de la Universidad de los Andes-ULA/Venezuela. Magister en Lingüística por la Universidad Central de Venezuela-UCV/Venezuela. Es profesora asesora de la Universidad Nacional Abierta, Centro Local Lara/Venezuela. Colaboradora del grupo de investigación "Ressignificações do passado na América Latina: leitura, escrita e tradução de gêneros híbridos de história e ficção - vias para a descolonização", liderado por el Prof. Dr. Gilmei Francisco Fleck. E-mail: rafkolnikov@gmail.com.
} 
problemáticas contemporâneas, caso da obra poética de Julia Otxoa (1953) e Idea Vilariño (19202009), cujos textos serão analisados sob essa ótica.

\begin{abstract}
The relation between Literature and History can be traced back since the very beginning of the conformation of human societies. In the lyrical genre one can observed this influence in classical works such as the Cantar del Mio Cid (anonymous), is Spain; and Os Lusíadas (1572), in Portugal. In them, the historical reference was used to show up national pride and exaltation of heroes and their achievements. Instead, in our more recent Poetry (written along the XX and XXI centuries), this confluence is conceived as a critical aptitude which leads to complaints and reflections concerning problematical situations of nowadays life, as we can see in Julias Otxoa's (1953) an Idea Vilariño's (1920-2009) poetry, whose poems will be analyses by us under this point of view.
\end{abstract}

Keywords: Julia Otxoa, Idea Vilariño. Historical poetry. History and Literature.

\title{
Introducción
}

La Literatura y la Historia comparten una intensa y antigua relación que se puede observar en las diferentes producciones de carácter narrativo, dramático y lírico que han dejado un legado cultural a las sociedades actuales. En particular, el cultivo de la poesía fue parte inherente en la constitución de los pueblos y la cultura. En palabras de Octavio Paz (2003, p. 68-69), mientras que hay pueblos sin prosa no los puede haber sin poesía; "es inconcebible la existencia de una sociedad sin canciones, mitos u otras expresiones poéticas"; lo que hace del género el lugar donde de forma más fructífera se da esa confluencia de lo literario con lo histórico.

El antecedente más remoto lo encontramos en el género de la epopeya, cuyos temas oscilan entre las aventuras de una colectividad y las de su héroe sublime que, gracias al enaltecimiento, grandilocuencia, admiración y dominio del lenguaje del poeta que las canta, adquieren dimensiones simbólicas múltiples que sobrepasan la simple barrera de la "veracidad". Para los pueblos ibéricos son importantes registros de esa relación el Cantar del Mío Cid (Anónimo) - probablemente compuesto a finales del siglo XII o en los primeros años del siglo XIII- y la obra maestra del portugués Luiz de Camões, Os Lusíadas (1572). Conforme nos informa Mata Induráin (1995, p. 28), en la época cuando aparecen estas dos obras -donde la historia y la poesía se hibridizan -, "[...] no existía una consciencia histórica plena, rigorosamente científica, que permitiera deslindar claramente lo cierto y lo fabuloso, lo histórico y lo legendario [...]."

El poema como producto artístico o literario, está asociado en mayor medida a los aspectos de carácter subjetivo del ser humano. Por tanto, se produce desde una mirada más personal, sin que, aparentemente, tenga ninguna conexión con los hechos sociales. No 
obstante, el poeta no puede deslindarse ni de la sociedad en que ha nacido y vive ni de la historia que le es propia. De forma consciente o no, extrapola su vivencia personal en el discurso lírico, demostrando, como lo expresa el crítico venezolano Márquez Rodríguez (1991, p. 9), que "el interés del hombre por el pasado es constante."

En la poesía actual, observamos como el sujeto poético, lejos de dar cuenta de los hechos históricos a manera de sentimentalidad lírica o simple descripción, muestra ante éstos una actitud reflexiva y crítica, ética o políticamente comprometida, caso de las escritoras Julia Otxoa e Idea Vilariño. Otros poetas prefieren dirigirse conscientemente al pasado de sus sociedades para resignificar ciertos acontecimientos registrados en los anales de la historiografía bajo una perspectiva divergente de la que consignó la visión primera, como, por ejemplo, el poeta chileno Pablo Neruda en "Alturas de Machu Picchu" (Canto General, 1950). Para efectos de este artículo, se optó por el estudio de poemas que se inclinan hacia esa primera tendencia, textos donde queda expresada una firme relación de lo poético con eventos históricos de carácter político y/o bélico que aún se mantienen en la memoria histórica de las sociedades que los padecieron.

\section{Las poetas que cuentan la historia: Idea Vilariño y Julia Otxoa}

Una de las ideas sobre el quehacer poético y artístico que a Julia Otxoa le interesa dar a conocer en sus entrevistas ${ }^{3}$ y demás intervenciones públicas, así como demostrar a través de su trabajo artístico y literario - en el que se incluyen poesía, narrativa, ensayo y poesía visual - es la de que "el escritor debe estar cosido a su tiempo". Con esta afirmación, la autora vasca define una postura ética frente a su condición de escritora que va a determinar una poética que, en todas sus formas, se nutre de unas mismas preocupaciones e intenciones: la de un hombre deshumanizado en desequilibrio con su entorno y con el otro, y la necesidad de que nos veamos en él, el hombre contemporáneo, el mismo con el que a ella le ha tocado

\footnotetext{
${ }^{3}$ Sugerimos escuchar una de las encuestas de la poeta, disponible en ASOCIACIÓN ESCRITORES EUSKADI [entrevista a Julia Otxoa realizada por Ángeles Encinar en Donostia, San Sebastián, con la colaboración del Departamento de Cultura del gobierno vasco en fecha 16/09/2011]. En: https://www.youtube.com/watch?v=UWjiba_Gseg\&t=968s. Consultado en 15 ago. 2019.

${ }^{4}$ Mención hecha en una entrevista a la poeta, disponible en MOYANO, Alberto. "El escritor debe estar cocido a su tiempo" [entrevista a Julia Otxoa en el Diario Vasco en fecha 23/07/2008]. En: <http://www.diariovasco.com/20080723/cultura/escritor-debe-estar-cosido-20080723.html>. Consultado en 24 dez. 2018.
} 
convivir en un contexto de guerra y en el que podemos encontrar la carga de historicidad que comporta su obra.

Nacida en 1953, a Otxoa le correspondió vivir los últimos 22 años de la dictadura franquista y, en su totalidad, toda la experiencia del terrorismo etarra ${ }^{5}$ y su combate no menos violento por parte del gobierno español; además, el recuerdo de la Guerra Civil (1936-1939) y los sucesos de postguerra que le transmitieron sus familiares, algunos de ellos asesinados en ese período.

Como cualquier ciudadano nacido en tierra vasca, la autora no es ajena a las tensiones ideológicas que aún subsisten en esa nación por motivo del reclamo al derecho de autodeterminación ante España y la reafirmación de la identidad, especialmente centrada en el uso del idioma originario, el euskera; lengua que no todos los vascos hablan y/o escriben, posiblemente, a causa de su complejidad gramatical, la situación de bilingüismo que siempre ha mantenido con la lengua española, o su desuso durante el tiempo del Franquismo coincidente con la etapa de escolaridad de esta autora - cuando estuvo censurado para la comunicación oficial.

Las anteriores circunstancias históricas hacen de la obra de Otxoa un instrumento discursivamente pragmático que tiende hacia propósitos éticos, en el seno del contexto social vasco-español y, por extensión, en el contexto más amplio de las sociedades que padecen la violencia como respuesta a sus diferencias políticas o con otros orígenes.

¿Cómo fue posible para ti relatar el horror?” - se pregunta el sujeto poético en la primera estrofa del poema 59 del libro Jardín de arena (2014, p. 62-63), último poemario publicado por la autora vasca -; interrogantes que se dirigen a Hannah Arendt, personaje de la historia que selecciona Otxoa para ofrecer de manera indirecta un primer referente sobre la guerra, posibilitando un escenario inicial de reflexión que debe ocupar el lector para luego llegar a apropiarse de unos mensajes concretos respecto a este tema. En esta primera estrofa se lee: "Hannah ¿cómo fue posible para ti relatar el horror?,/¿la banalidad del mal,/¿dónde hallaste la serenidad?" (OTXOA, 2014, p. 62).

Leídas las siguientes dos estrofas, la voz poética continúa dirigiéndose a Arendt como quien se refugia en una especie de deidad para pedir consolación, en un estilo conversacional

\footnotetext{
${ }^{5}$ Más informaciones disponibles en JOVATO, Víctor (2011): "ETA. Origen e ideología”. En: Ab Initio. № 3, pp. 143-163. En: http://www.ab-initio.es/wp-content/uploads/2013/03/0308-ETA.pdf. Consultado en 24 dez. 2018.
} 
y confidente que nos recuerda a los líricos griegos. Esta voz comienza a personalizarse expresando una sentimentalidad propia de padecimiento e inconformidad, de búsqueda y espera y de decidida decepción:

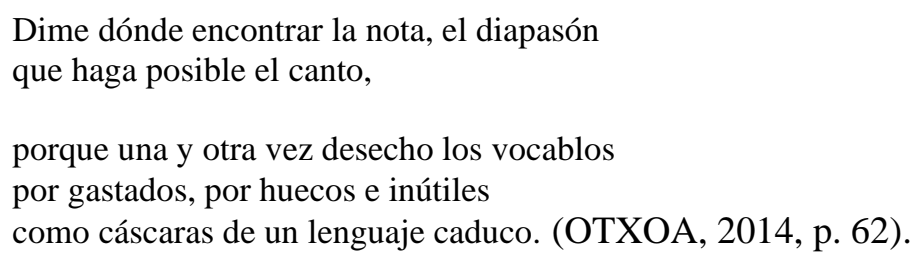

Una imagen cognitiva inmediata que se asocia a la figura de Arendt es la del holocausto judío en la Segunda Guerra Mundial (1939-1945). En el poema, este hecho le sirve entonces a Otxoa como signo de extrapolación de una guerra en particular, bien sea que se trate de los sucesos de terrorismo en el País Vasco, vigentes para la fecha de la publicación de Jardín de arena (2014) o la situación de exterminio que se vivió a partir del golpe de estado a la Segunda República (1931-1939) y continuó con la Guerra Civil (1936-1939) y la dictadura (1936-1975), símbolos vivos de opresión y dolor para la colectividad vasco-española, aún después de llegada la democracia.

Ciertamente, estos sucesos podrían compararse con el antisemitismo criminal que acompañó el nacionalismo de Hitler, al no tener bases reales que no sean el fanatismo o la ciega obediencia hacia posturas totalitarias o extremas que han derivado en verdaderos delitos humanitarios, lo que la filósofa judía explica como banalidad del mal: una ausencia o incapacidad de pensamiento reflexivo que llevaría a cualquier persona, independientemente de su inteligencia, a no discernir entre lo que está bien o no en el momento de sus actuaciones en contra de otros seres humanos (ARENDT, 1999).

No es sino hasta la cuarta estrofa del poema, cuando se presenta una imagen directa alusiva a la muerte, la de unos huesos que no están enterrados - "miles de esqueletos claman insepultos tras la ventana" (OTXOA, 2014, p. 62) -, acompañada de información histórica socialmente compartida, que aunque no pudiera dar referencias exactas de cualquiera de los momentos bélicos antes mencionados, le permite al lector estar frente a una voz de denuncia y en un contexto de guerra, como se puede observar en los versos que siguen:

Sé que debo hacerlo miles de esqueletos claman insepultos tras la ventana, no pertenecen al registro oficial de víctimas, 
tan solo son pobres huesos del bando perdedor apenas nada para los cómplices del olvido. (OTXOA, 2014, p. 62).

Tanto en la quinta estrofa como en la sucesiva se amplía esa información histórica y se introducen nuevos referentes que, finalmente, permiten revelar la figura del dictador y afirmar que, en efecto, "los miles de esqueletos" son todos aquellos republicanos o demócratas asesinados durante el golpe de estado de 1936, la Guerra Civil (1936-1939) y la dictadura (1936-1975) abandonados a su suerte o depositados en fosas comunes fuera de los cementerios, de quienes se desconoce su paradero; lo mismo no ocurrió con los restos del bando franquista que, luego de la guerra, fueron objeto de investigación y traslado inmediato hacia las criptas del Valle de los Caídos ${ }^{6}$, (FERRÁNDIZ, FLORES, GARCÍA, LÓPEZ Y TOMÉ, 2019, p. 75), una edificación funeraria y religiosa que Francisco Franco (1892-1975) construyó como homenaje a las víctimas de la Guerra Civil (1936-1939).

Adicionalmente, el verso inicial de la quinta estrofa presenta un pie de página en el texto original donde se lee: "In Memoriam de mi abuelo Balbino García de Albizu Usarbarrena, asesinado por rojo el 7 de septiembre de 1936 en la sierra de Urbasa (Navarra)." (OTXOA, 2014, p. 63). En esta estrofa leemos:

Su vana espera ha durado setenta y siete años,

Siempre ha sonado silencio para ellos,

El fascio, rancio ensotanado de España,

no ha dejado de mandar un solo día. (OTXOA, 2014, p. 63).

Durante la transición hacia la democracia en España se llevaron a cabo un conjunto de acciones gubernamentales para reparar los daños de la Guerra Civil (1936-1939) y el Franquismo que incluían indemnizaciones y beneficios sociales para las víctimas del bando republicano (privilegio que sí tuvieron las víctimas contrapuestas) además de una Ley de Amnistía (1977) que eximía de pena a todos los que hubieran actuado ilegalmente en favor o en contra del régimen.

Al mismo tiempo, se mantuvo una posición de olvido o silencio hacia el pasado de guerra y dictadura como una estrategia de pacificación que, se creía, evitaría un nuevo desencadenamiento de odios o conflictos sociales; lo que algunos intelectuales, historiadores

\footnotetext{
${ }^{6}$ Sugerimos ver el documentario "Francisco Franco: 3 claves para entender las razones de su exhumación del Valle de los Caídos en España (y a donde lo trasladaron)" [nota publicada en BBC News Mundo en fecha 14/10/2018]. En: https://www.bbc.com/mundo/noticias-internacional-50144938. Consultado en 02 feb. 2020.
} 
y familiares de la víctimas antifranquistas toman como un encubrimiento intencional de la historia que continuaba invisibilizando la verdad y creaba un clima de desconfianza hacia la naciente institucionalidad democrática sobre su verdadero deslastre de las viejas ideologías y prácticas dictatoriales (BARROS, 2014).

Dentro de este panorama, las demandadas por dignificar a las víctimas del lado republicano y conocer la ubicación de su restos no fueron satisfactoriamente atendidas hasta crearse en 2007 la Ley de memoria histórica, donde se amplía el marco de actuación para las acciones indemnizatorias y establecen otras prerrogativas que favorecen la exhumación de cadáveres; sin embargo, por motivos burocráticos, debilidades en la Ley, actitudes de autocensura hacia un pasado traumático y la complejidad de las mismas tareas de exhumación, la Ley no fue un instrumento completo y eficaz de apoyo a las víctimas, con lo que el gobierno de entonces no pudo demostrar un compromiso real en esta materia.

Con la llegada de una nueva presidencia, se cierra la oficina encargada de diligenciar las solicitudes de los beneficiarios de la Ley (marzo de 2012), las víctimas quedan nuevamente en desamparo y queda la sensación de que el Estado democrático está dando continuidad a la injusticia del antiguo régimen; probablemente, lo mismo que se puede estar connotando en el poema de Otxoa al decirse que "El fascio, rancio ensotanado de España no ha dejado de mandar un solo día" y que hay una "vana espera" de "setenta y siete años" de parte de los muertos, que en realidad es la espera de sus familiares, este último dato casi exacto si se cuenta el tiempo que ha transcurrido desde 1936 hasta 2014, fecha de publicación de su libro.

En este sentido, es clara la intención de denuncia contenida en el poema, así como la solidaridad de su autora con las víctimas al no dejar de recordarnos tanto los crímenes como a quienes estuvieron involucrados en ello: la iglesia católica y las instituciones encargadas de administrar justicia subordinadas al mando militar.

En la sexta estrofa, Otxoa nos muestra una imagen casi fotográfica de la magnitud virulenta y desmesurada de los muertos en un extenso escenario que incluye lo rural y lo urbano, lo cívico y lo jurídico, lo público y lo privado, refiriendo que se trata de un problema actual cuya responsabilidad se vincula a todo un país y a sus instituciones: 
bajo todo los libros de la leyes

brillan las calaveras. (OTXOA, 2014, p. 63).

Las cifras siguientes nos permiten tener un indicador de la imagen de Franco (18921975) vinculada a la muerte y al daño social: 150.000 asesinatos en el campo de batalla; entre 110.000 y 150.000 desaparecidos; aproximadamente 200.000 personas que, entre abril de 1939 y enero de 1940, murieron en las cárceles como presos políticos y la existencia de unas 2.300 fosas comunes; sin hacer mención de muchas otras acciones en contra de los derechos humanos de las que el dictador es responsable, como el robo sistemático de niños recién nacidos - en sus inicios, a causa de motivos ideológicos -, desde la posguerra y hasta la década de los 90, que ha hecho que unas 300.000 personas desconozcan a sus verdaderas familias (LÓPEZ, 2015, p. 136-137).

La vinculación del clero, tal como aparece simbolizada en esta última estrofa, no fue menos importante dentro de esa política represiva. Durante el Franquismo la iglesia actuó como "una agencia de investigación parapolicial" donde los párrocos suministraban información sobre los antecedentes (antes y después de la fecha del Golpe de Estado) del presunto responsable; además era función de los sacerdotes preparar informes sobre las cualidades morales de los presos: "si el sujeto había abjurado de sus errores o no, si se caracterizaba por una buena conducta pública o privada" (PORTILLA, 2012, p. 194-198), informes que se parcializaban perjudicando intencionalmente a los procesados de los que se sospechaba o comprobaba su relación con ideologías opositoras.

Todo este escenario de criminalidad y represión, en el caso del País Vasco, lamentablemente no terminó con la muerte de Franco (Ferrol, 4 de diciembre de 1892 Madrid, 20 de noviembre de 1975); por el contrario, se vivió una violencia exacerbada protagonizada por $\mathrm{ETA}^{7}$, tácitamente apoyado por un sector de la población civil y la iglesia vascas, quienes al ver frustrada la causa independentista en manos de los nuevos actores políticos vieron en la organización armada una opción válida de lucha.

Desde 1968 hasta 2010, mueren 829 personas a causa de la violencia etarra: políticos, policías, militares y civiles. Son especialmente recordados los llamados años de plomo (década de los 80 y principios de los 90) cuando se ejecutaron varios atentados en lugares

\footnotetext{
${ }^{7}$ Más informaciones en el video "Víctimas: la historia de ETA" [parte 4 (Los años de plomo: Madrid como objetivo) en youtube de la serie documental producida por el El Mundo TV para TELEMADRID 2006]. En: https://www.youtube.com/watch?v=gG4867wZ_iA\&list=PL5Elc2OLiWk7tSQhUwDWF3dF7UxBoG44f\&inde $\mathrm{x}=4$.
} 
públicos; entre ellos la plaza República de Argentina (1985), la calle Juan Bravo (1986), la plaza República Dominicana (1986), el hipermercado Hipercor (1987) y la Casa Cuartel de Vic (1991).

Por su parte, el gobierno español en su combate al terrorismo ha dado continuidad a las prácticas de la dictadura actuando impunemente, de forma inconstitucional o violando los derechos humanos: detenciones y torturas a personas de las cuales se sospechaba una vinculación con ETA; dispersión de los presos políticos vascos fuera de su lugar de residencia (en cárceles de España y Francia); muerte de presos políticos por motivo de tortura; largas condenas por delitos no comprobados o injustificados (como izar la bandera vasca en lugares públicos); y poca o nula atención judicial al caso de la extorsión de los empresarios vascos y franceses quienes, bajo amenaza de muerte, debían pagar a la organización, con el 1\%, de sus ganancias, el llamado "impuesto revolucionario", dinero que se destinó a la compra de armas y al financiamiento general de ETA. También habría que mencionar la vinculación del gobierno de Felipe González con los GAL (Grupos Antiterroristas de Liberación) que actuaron contra ETA con medios ilícitos como la tortura, el secuestro y el asesinato (CARNEVALI, 2015, p. 205).

Aunque en el texto que se analiza el referente histórico general son la Guerra Civil (1936-1939) y la dictadura, no es desacertado decir que esa sensibilidad de la autora frente al dolor humano y compromiso ético también se nutre de esa historia de terrorismo que le tocó vivir y que, al fin y al cabo es la verdadera guerra de la que ella es testigo. Desde allí, probablemente, es de donde ella puede hacer un mejor examen del mal y cargarse de una sensibilidad directa que marcará su proyecto poético en el que hay una preocupación especial por el olvido a toda esa violencia y criminalidad que han marcado a su país y al sangriento siglo $\mathrm{XX}$, una realidad que queda manifiesta en los siguientes versos:

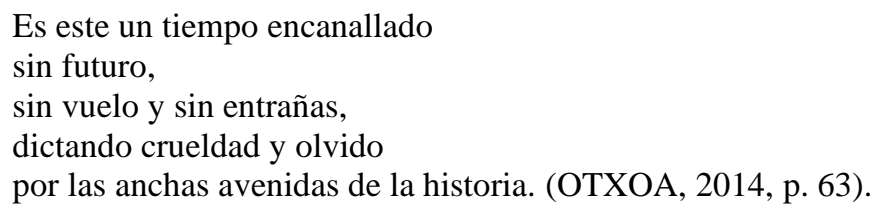

En la totalidad del poema, observamos una perspectiva lírica donde se dialoga directamente con la realidad histórica. Por un lado, esto se logra con la mención de un año que es clave para la sociedad vasco-española y la sociedad mundial en la historia de las guerras 
más recientes, "el 36" (sexta estrofa), que nos ubica en un contexto y unos actores precisos: el de la Guerra Civil Española (1936-1939) y a su protagonista más importante, Francisco Franco (1892-1975), con toda la situación de criminalidad e injusticia que a él se asocia; por otro, con la presencia de Hanna Arendt que, simbólicamente, representa no sólo la comprensión desde la razón y una actitud de resistencia y denuncia hacia la violencia, sino que le vale a Otxoa como aliada, argumento y verdad de su propio discurso y sus propias intenciones de asumir el malestar humano desde sus justas dimensiones éticas. Una misma inclinación se evidencia en la obra de nuestra segunda autora, la poeta uruguaya Idea Vilariño, de quien nos ocuparemos a continuación.

La obra de Vilariño, una de las grandes voces femeninas de la literatura de América, al igual que en Julia Otxoa no sólo se nutre de la lírica, sino también de la traducción, la teoría lírica y la crítica literaria. Esta escritora, nacida en la primera mitad del siglo pasado (19202009), vivió un período histórico conturbado para el continente y el mundo con los diversos problemas que aquejaron la década de 1960, especialmente los acontecimientos bélicos de la Segunda Guerra Mundial (1939-1945) y la Guerra Fría (1947-1953).

Su poesía, enmarcada dentro de la corriente existencialista, versa sobre temas como el amor, la muerte y el paso del tiempo. Entre los temas que la autora explora también se encuentran los de contenido político-histórico. Los poemas de esta clase muestran un sujeto discursivo comprometido con su realidad local y universal, caso del texto "En la noche de luna", poema que se selecciona como texto de estudio para analizar sus conexiones con las problemáticas sociales que circundan al momento histórico de su producción.

El poema se extrae del libro Pobre mundo (1966), un libro dividido en dos partes: en la primera, se revela una reflexión sobre las precarias condiciones de supervivencia del planeta y una crítica hacia las acciones destructivas del hombre; en la segunda, el repudio a las políticas expansionistas de los Estados Unidos, a las guerras y a las condiciones de una América tercermundista. De esta segunda parte proviene el texto objeto de análisis, donde, particularmente, el sujeto poético muestra una preocupación por Latinoamérica. En él se intercalan y contrastan la belleza del existir con las catástrofes que han padecido y aún sufren las sociedades de esta parte del mundo y en general las más desfavorecidas:

\section{En la noche de luna}

En medio de esta enorme noche blanca 


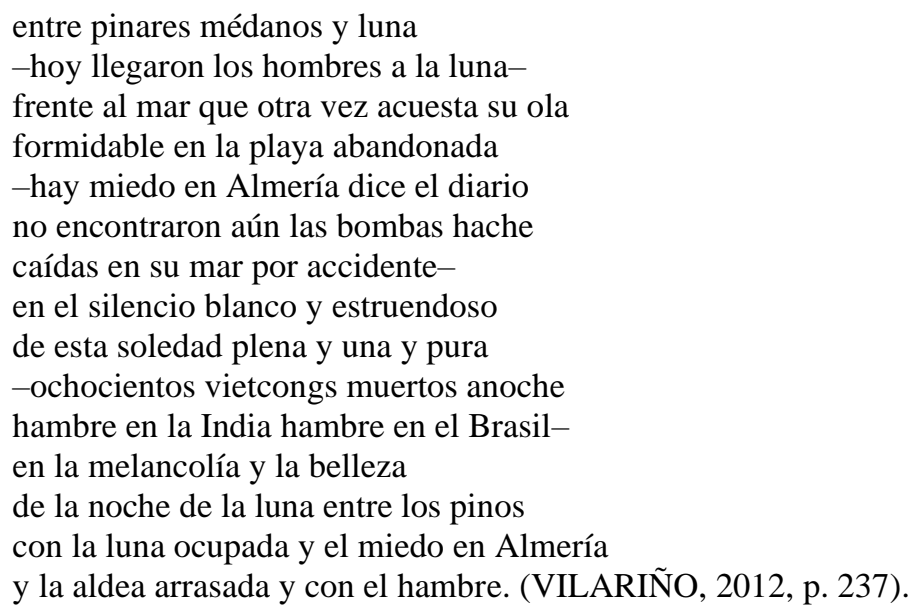

El poema se conforma de dieciséis versos endecasílabos que, entre ellos, carecen de una separación marcada y sólo utilizan guiones y punto final como únicos signos de puntuación. La reducida presencia de signos es un recurso escritural usado con frecuencia por Vilariño en varias de sus producciones. Este recurso sugiere la necesidad de una expresión más ágil, con cierta impaciencia, quizá un signo de desahogo a través de las palabras. Los guiones, que encierran una información, crean un texto paralelo de modo estratégico por parte de la autora, quien mediante la yuxtaposición de versos invita al lector a aceptar dos discursos que se contrastan.

En el entramado de imágenes expuestas tenemos las siguientes visiones: las hazañas humanas en el orden tecnológico ("llegaron los hombres a la luna"); el miedo que atormenta a la gente ("hay miedo en Almería"); las guerras que destruyen hombres y entornos geográficos ("ochocientos vietcongs muertos"); y el hambre que hace sufrir a la gente alrededor de mundo ("hambre en la India hambre en el Brasil").

Todas esas visiones son comentadas de modo descriptivo y emotivo, en un momento apacible, mientras que el personaje que protagoniza la voz poética se encuentra en la orilla del mar contemplando entre los pinos la noche de luna. En la escena, se muestran al lector dos universos distintos, el bucólico y el histórico, los cuales logran fundirse en los últimos dos versos del texto: "con la luna ocupada y el miedo en Almería / y la aldea arrasada y con el hambre".

Estructuralmente, el poema se distribuye de manera tripartita, configurando dos discursos coexistentes - a los que vamos a denominar "primera" y "segunda" partes -. A estas fracciones se une una "tercera" que recoge una visión conjunta de esos dos discursos. 
En la primera parte, la composición ofrece la imagen de un personaje, el sujeto discursivo, que frente a un hermoso paisaje nocturno - "En medio de esta enorme noche blanca / entre pinares médanos y luna"- reflexiona mirando el cielo y pensando en la vida.

En la segunda, envuelto en esa atmósfera de deslumbramiento, este personaje se enfrenta a un hecho histórico, segundo momento, formalmente puesto entre guiones para destacar, una de las primeras informaciones que le afectan "-hoy llegaron los hombres a la luna-". El ejemplo mencionado del texto se interrumpe con este primer entrecruzamiento de visiones. Ese cuadro nocturno de contornos apacibles termina en una imagen paradisíaca: "frente al mar que otra vez acuesta su ola / formidable en la playa abandonada".

Los opuestos -"primera" y "segunda" parte - quedan en evidencia cuando el lector realiza el ejercicio de desconstrucción y reorganización de los dos polos que se interconectan en la estructura, cuyo resultado es la descripción bucólica del escenario, es decir, la "primera" parte:

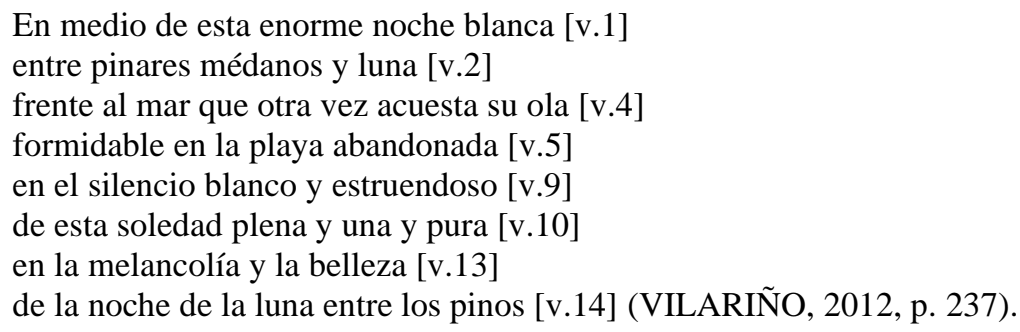

En esa primera "desconstrucción” y "reorganización” de versos, Vilariño nos ofrece un poema telúrico. Se nos presenta una escena nocturna de gran belleza con expresiones de carácter positivo: "blanca(o)", "formidable", "pura", "belleza" que remiten al lector a un espacio paradisíaco en el cual reina "el silencio blanco" de una "playa abandonada", sugiriendo sentimientos muy íntimos del sujeto lírico: "soledad plena" y la "melancolía", que encuentran acogida en "la belleza de la noche de la luna entre los pinos".

De esta manera, el universo se presenta - en esta primara parte "desconstruida y reorganizada" - como un espacio apacible, armónico y acogedor para el personaje que, a primera vista, parece encontrar en el "blanco" de la noche, sin máculas y disturbios, el espacio de plena expansión y libertad. La "luna", que se presenta de un modo idealizado, se destaca como centro de esta parte telúrica de la composición. 
En la segunda composición -o "segunda" parte- que emerge del ejercicio de “desconstrucción” y "reorganización” de los versos, se expresa, explícitamente, una crítica social contundente. La voz poética nos intenta concientizar sobre una realidad circundante ante la que no podemos cerrar los ojos, fingiendo no ver nada dentro de un mundo apacible "de una noche blanca de luna".

A continuación, aislamos los versos intercalados de la escena bucólica que describe la voz poética en su refugio de una "playa abandonada" - que componen la "primera" parte del poema. Tales versos nos dan la esencia de la crítica social pungente que se interconecta con la escena nocturna, generando la "segunda" parte del poema:

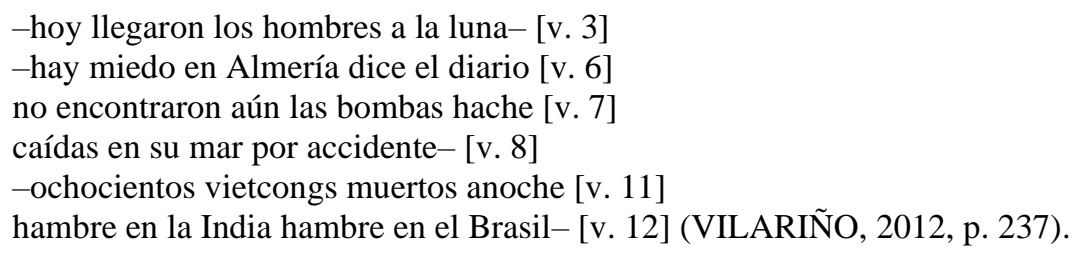

En la nueva construcción tenemos al sustantivo "luna" fuera del foco de la idealización poética, presentándose simplemente como el satélite natural de la tierra, conquistado por los hombres. Los versos siguientes hacen referencia al conflicto social que se vive en España con relación a la Guerra de Vietnam (1955-1975) y los graves problemas económicos de países como la India y Brasil.

Encontramos en los versos que integran la "tercera" parte un carácter dialógico que se establece por medio de la convergencia de dos discursos que revelan imágenes opuestas: lo "apacible" y lo "bélico", lo "blanco y bello", "el miedo y el hambre". Este dialogismo se concreta en las imágenes - "con la luna ocupada y el miedo en Almería [v. 15] / y la aldea arrasada y con el hambre [v. 16]" - de los dos últimos versos del texto. En esos dos versos finales, queda fijada la visión crítica amplia del momento histórico en que se inserta esta composición que privilegia discursos opuestos imbricados en una estructura dialógica que exige la participación activa del lector para la "reconstrucción" de los sentidos.

Vilariño deja claro en su escritura que bajo la misma luna y en el mismo mar hay universos opuestos que se encuentran en conflicto. Frente a un sentimiento de "soledad plena" y de "melancolía", la escritora inserta algunos de los acontecimientos históricos más relevantes y problemáticos de la década de 1960: la llegada del hombre a la luna - que causó la carrera armamentista entre Estados Unidos y Rusia; la Guerra de Vietnam (1955-1975); el 
accidente de Palomares $^{8}$, hecho ocurrido en España el 17 de enero de 1966; y el hambruna del Brasil y de la India.

En el poema tenemos una muestra de cómo la poeta busca por medio de su producción lírica concientizar a la sociedad en la que vive de que no puede quedarse aislada de los problemas mundiales que afectan la humanidad como un todo. Entendemos que la poeta invita a que la gente debe preocuparse por perseguir un mundo más fraternal; asunto cada vez más urgente frente a tantos acontecimientos históricos desastrosos.

\section{Consideraciones finales}

Al leer la obra de escritoras como Julia Otxoa e idea Vilariño podemos ver al poema desde otra dimensión histórica, como un potente instrumento discursivo de denuncia y apertura a la reflexión que invita a cualquier lector a rectificar desde los espacios en que cualquiera de nosotros, ciudadanos comunes y corrientes puede hacerlo, nuestras propias facultades para pensar y concientizar los hechos.

En el caso de la autora vasca, concientizar sobre el olvido de la historia y, desde allí ver en la memoria un arma social importante para crear nuevos valores de convivencia y de rechazo a la guerra; y en el de la poeta uruguaya, el rescate de la sensibilidad hacia a un mundo cada vez más deshumanizado donde imperan grandes contraste de desigualdad y el hombre es testigo ciego de su propia deshumanización.

\section{Referencias}

ÁLVAREZ JUNCO, José (2010): "La ley de víctimas de la Guerra Civil y el Franquismo". En: Historia contemporánea. $\mathrm{N}^{\circ} 38$, pp. 145-161. ISNN 1130-2402. Universidad Complutense de Madrid. En: <https://www.ehu.eus/ojs/index.php/HC/article/view/2730>. Consulta: 26/01/2020.

ARENDT, Hannah. Eichmann en Jerusalén. 4ta ed. Barcelona: Lumen, 2003.

ARZUMENDI, Mikel. La herida patriótica. Madrid: Taurus, 1998.

\footnotetext{
${ }^{8}$ La escritora se refiere al Incidente de Palomares que ocurrió el 17 de enero de 1966, cuando un bombardero B$52 \mathrm{G}$ de la fuerza aérea de los Estados Unidos colidió con un Boeing KC-135, mientras éste lo reabastecía en pleno vuelo arriba del Mar Mediterráneo. El B-52G cargaba cuatro bombas de hidrógeno del tipo MK28, de las cuales tres acabaron cayendo en el pequeño poblado de Palomares en el municipio de Cuevas del Almanzora, Almería, España. Una de las bombas quedó intacta a la caída y las otras dos tuvieron sus explosivos no nucleares detonados, lo que resultó en una contaminación de dos $\mathrm{km}$ cuadrados de plutonio, la cuarta bomba acabó cayendo en el Mar Mediterráneo y fue recuperada algunos meses después.
} 
BARROS, Carlos. "Historia, memoria y franquismo". En: Hao. $\mathrm{N}^{\circ}$ 33, pp. 153-171. ISSN 1696-2060, 2014. En: <https://dialnet.unirioja.es/servlet/articulo?codigo=4611866>. Consulta: 26/01/2020.

CARNEVALI, Raúl. "El terrorismo de estado como violación a los derechos humanos. En especial la intervención de los organismos estatales". En: Estudios constitucionales. Revista del Centro de Estudios Constitucionales de Chile. $\mathrm{N}^{\circ}$ 2, vol. 13, pp. 203-235. 2015. ISNN 0718-0195. En: <https://scielo.conicyt.cl/pdf/estconst/v13n2/art08.pdf>. Consulta: 01/03/2020.

FERRÁNDIZ Francisco, FLORES, Juan Antonio, GARCÍA, María, LÓPEZ Julián y TOMÉ, Pedro. "Demanda Pedro Fausto Canales Bermejo. Informe pericial sobre víctimas del franquismo en la sociedad española contemporánea (15 de septiembre de 2012)". En: Éndoxa: series fiosóficas. $\mathrm{N}^{\circ}$ 44, pp.71-90. Madrid: Universidad Nacional de Educación a Distancia. En: <http://revistas.uned.es/index.php/endoxa/article/view/25941>. Consulta: 28/01/2020.

LÓPEZ, Pedro. "Crímenes del franquismo, derecho y justicia transicional". En: Derecho y realidad. $\quad \mathrm{N}^{\circ}$ 25, vol. 13, pp. 131-144, 2015. ISSN-e 1692-3936. En: https://revistas.uptc.edu.derecho_realidco/index.php/ad/article/view/4422/3759. Consulta: 26/01/2020.

MÁRQUEZ RODRÍGUEZ, A. Historia y ficción en la novela venezolana. Caracas: Monte Ávila, 1991.

MATA INDURÁIN, C. Retrospectiva sobre la evolución de la novela histórica. In: VÁRIOS. La novela histórica: teoría y comentarios. Barañáin: EUNSA, 1995.

OTXOA, Julia. Jardín de arena. Madrid: Ediciones La Palma, 2014.

PAZ, Octavio. Convergencias. Barcelona: Seix Barral, 1991.

PORTILLA, Guillermo. "Colaboración de la iglesia católica en la represión penal de la masonería y el comunismo durante el franquismo". En: Revista penal de México. № 3, pp. 193-201.

2012.

En:

http://rabida.uhu.es/dspace/bitstream/handle/10272/14260/colaboracion_de_la_iglesia.pdf?seq uence=2. Consulta: 21/01/2020.

VILARIÑO, Idea. Poesía completa. Montevideo: Cal y Canto, 2016.

Recebido em 21 de janeiro de 2020.

Aceito em 18 de abril de 2020. 